\title{
PERBANDINGAN PEMBERIAN ADSORBEN CANGKANG TELUR AYAM TERHADAP PENURUNAN BILANGAN ASAM DAN PEROKSIDA MINYAK JELANTAH PADA TEMPERATUR TINGGI DAN RUANG
}

\author{
Rodhiansyah Djayasinga ${ }^{1^{*}}$, Khairuni Fitriany ${ }^{2}$ \\ ${ }^{1}$ Prodi D-IV TLM Jurusan Analis Kesehatan, Poltekkes Tanjungkarang, Lampung, Indonesia \\ 2Laboratorium Pathologi Klinik, Rumah Sakit Abdoel Moeloek Provinsi Lampung, Indonesia \\ e-Mail : rodhiansyah@poltekkes-tjk.ac.id
}

\begin{abstract}
Quality improvement of the waste cooking oil can be conducted by reducing levels of acid number and peroxide number. The purpose of this study was to determine the levels of acid number and peroxide number, as well as the effective temperature of mixing chicken egg shell adsorbents to reduce the acid and peroxide levels. This research was an experimental study with two treatments. The first treatment used the waste cooking oil mixed to chicken egg shell adsorbent at high temperature, then stirred and separated into sediment and supernatant, then determined the levels of peroxide and acid number. The second treatment was carried out alike the first treatment procedure but placed at room temperature. As the independent variables in this study were temperatures that divided at high temperature and room temperature. As dependent variable of the study was levels of acid number and peroxide number.. The results of the study were analyzed using an Independent Bivariate T-test. It was found that there were significant differences in the levels of acid and peroxide ( $p$ value = 0,000 ) with a $95 \%$ confidence level. Based on univariate analysis test, it is known that the effective temperature is used to reduce the levels of free fatty acids and peroxide in used cooking oil using egg shell adsorbent at room temperature.
\end{abstract}

Key Words : Acid and Peroxide Numbers, Adsorbents, Used Cooking Oil

\begin{abstract}
Abstrak
Perbaikan mutu minyak jelantah dapat dilakukan dengan menurunkan kadar bilangan asam dan peroksida. Tujuan penelitian ini adalah untuk mengetahui kadar asam dan peroksida, serta suhu efektif pencampuran adsorben cangkang telur ayam untuk menurunkan kadar asam dan peroksida. Penelitian ini bersifat ekperimen dengan dua perlakuan. Perlakuan pertama sample minyak jelantah dicampur adsorben cangkang telur ayam pada temperatur tinggi, selanjutnya diaduk dan dipisahkan antara endapan dan supernatan, kemudian ditentukan kadar bilangan peroksida dan bilangan asam, perlakuan kedua sama seperti perlakuan pertama hanya berbeda temperatur yaitu pada temperatur ruang. Adapun variable bebas dalam penelitian ini adalah temperatur yang terdiri dari temperatur tinggi dan temperatur ruangan. Variabel terikat pada penelitian adalah kadar bilangan asam dan peroksida. Hasil penelitian dianalisa menggunakan bivariat uji Independen T-test diketahui terdapat perbedaan signifikan penurunan kadar bilangan asam dan peroksida ( $\mathrm{p}$ value $=0,000$ ) dengan tingkat kepercayaan $95 \%$. Berdasarkan uji analisa univariat diketahui temperatur efektif digunakan untuk menurunkan kadar asam lemak bebas dan peroksida dalam minyak jelantah mengunakan adsorben cangkang telur yakni pada temperatur ruang.
\end{abstract}

Kata Kunci : Adsorben, Bilangan Asam dan Peroksida, Minyak Jelantah 


\section{PENDAHULUAN}

Minyak jelantah adalah sebutan untuk minyak goreng yang sudah digunakan lebih dari 3-4 kali penggorengan. Di dalam minyak jelantah terdapat beberapa komposisi yang menjadi parameter diantaranya kadar air sebesar 0,5\%, asam lemak bebas (ALB) sebesar 4,71\%, berbau sedikit tengik dan berwarna keruh kecoklatan (Fitriyana, 2015) Minyak jelantah yang sudah memiliki kandungan tersebut tidak layak digunakan lagi dan jika dibuang dapat mencemari lingkungan, namun demikian dengan meningkatkan kualitas minyak jelantah dapat dimanfaatkan kembali sebagai bahan pembuat sabun, kosmetik dan juga biodiesel.

Badan Standarisasi Nasional telah menetapkan syarat mutu minyak goreng dalam SNI 01-3741-2013, yaitu maksimal 10 meq $\mathrm{O}_{2} / \mathrm{g}$ untuk bilangan Peroksida dan maksimal 0,6 mg KOH/g untuk bilangan asam. Bahaya tingginya asam lemak bebas pada minyak goreng bekas akan mengakibatkan keracunan dalam tubuh, dan berbagai macam penyakit seperti diare dan pengendapan lemak dalam pembuluh darah (Yulianti, 2018)

Peningkatan mutu minyak jelantah adalah salah satu upaya peningkatan kualitas minyak jelantah dengan cara menurunkan bilangan asam dan kadar asam lemak bebas. Berbagai metode telah dikembangkan dalam upaya penurunan kadar asam lemak bebas yang ada pada minyak jelantah antara lain; (1) (Fitriyana, 2015) menggunakan adsorben cangkang telur ayam yang diaktivasi fisika; (2) pemanfaatan sekam padi sebagai adsorbent (Schneider, 2019);(3) (Parvin, 2019) mengadsorpsi kongo merah menggunakan cangkang telur ayam;(4) (Hartono, 2020) menggunakan steam pada kolom vigrek dan katalis zeolit alam bayah. Banyak metode telah dikembangkan untuk pembuatan adsorben, namun metode adsorbsi masih menjadi unggulan karena kemudahan dalam perolehan bahan baku, proses yang sederhana, murah dan efektif.

Jasinda (2013) dalam Fitriyana (2015) menuliskan bahwa cangkang telur non aktivasi memiliki luas permukaan sebesar 12,955 $\mathrm{m}^{2} / \mathrm{g}$ sedangkan yang diaktivasi fisika pada suhu $600^{\circ} \mathrm{C}$ sebesar $2700,978 \mathrm{~m}^{2} / \mathrm{g}$. 
Pada penelitian ini menggunakan cangkang telur ayam ras, dimana cangkang telur tidak diaktivasi secara fisika, kemudian digunakan untuk mengadsorpsi kandungan senyawa peroksida dan asam lemak bebas yang tidak diinginkan dalam minyak jelantah. Teknik pencampuran adsorben cangkang telur ayam dicampurkan dengan minyak jelantah dilakukan pada dua temperatur yang berbeda yakni temperatur tinggi $\left(180^{\circ} \mathrm{C}\right)$ dan temperatur kamar. Berdasarkan dua perlakuan ini, dapat diketahui temperatur efektif untuk menurunkan senyawa peroksida dan asam lemak bebas.

\section{BAHAN DAN METODE}

Jenis penelitian ini bersifat experimental yaitu meneliti perbandingan nilai bilangan asam dan peroksida pada minyak jelantah yang diberi adsorben cangkang telur ayam pada temperatur tinggi dan rendah. Variabel bebas dalam penelitian ini adalah adsorben cangkang telur ayam yang diberikan pada minyak jelantah temperatur tinggi dan rendah. Variabel terikat adalah penurunan bilangan asam dan bilangan peroksida. Penelitian ini telah dilakukan pada bulan Juli hingga Oktober 2018 di Laboratorium kimia Air, Makanan, dan Minuman (AMAMI) Poltekkes Tanjungkarang, Jurusan Analis Kesehatan. Subjek penelitian ini yaitu minyak jelantah yang diberi 2 perlakuan temperatur pada saat adsorben digunakan untuk mengurangi asam lemak bebas dan peroksidaserta masing-masing temperatur dilakukan 15 kali pengulangan.

Peralatan yang digunakan antara lain: oven, crusher, furnace, desikator, hot plate, neraca analitis, pompa vakum, erlemeyer $250 \mathrm{~mL}$. Sample minyak jelantah, adsorben cangkang telur ayam. Bahan kimia yang digunakan antara lain larutan KI jenuh; kloroform; asam asetat glasial; aquadest; larutan $\mathrm{Na}_{2} \mathrm{~S}_{2} \mathrm{O}_{3}$ $0,05 \mathrm{~N}$; indikator larutan kanji 1\%; $\mathrm{KIO}_{3} 0,05 \mathrm{~N} ; \mathrm{H}_{2} \mathrm{SO}_{4} 2 \mathrm{~N}$; larutan $\mathrm{KI} 10 \%$; $\mathrm{KOH}$ $0,1 \mathrm{~N} ; \mathrm{H}_{2} \mathrm{C}_{2} \mathrm{O}_{4} 0,1 \mathrm{~N}$; Indikator fenolftalein (pp) $1 \%$; alkohol 95\% netral.

\section{Prosedur Pembuatan Adsorben Cangkang Telur Ayam}

Tahapan dari penelitian ini dimulai dari cangkang telur ayam ras dicuci beberapa kali hingga bersih kemudian direbus. Lapisan membran dipisahkan dari cangkangnya kemudian dikeringkan pada suhu ruang. Selanjutnya 
cangkang telur digerus menjadi partikel kecil kemudian disaring.

\section{Prosedur Perlakuan Sampel}

Adapun perlakuan sampel yang dilakukan dalam beberapa tahap yaitu tahap (1), $100 \mathrm{~mL}$ minyak jelantah dimasukkan ke dalam erlenmeyer kemudian dicampurkan 20 gram adsorben cangkang telur ayam (perbandingan 5 bagian minyak jelantah dicampurkan dengan 1 bagian adsorben) dicampurkan ke dalam erlenmeyer yang berisi minyak jelantah kemudian dihomogenkan menggunakan alat sentrifuse dengan kecepatan putaran 2000 rpm selama 25 menit kemudian dipisahkan supernatan dan endapan.

Tahap (2), Selanjutnya supernatan diberi perlakuan pencampuran adsorben cangkang telur kembali dengan perbandingan sama, kemudian supernatan dihomogenkan menggunakan alat sentrifuse dengan kecepatan putaran 2000 rpm selama 25 menit kemudian dipisahkan supernatan dan endapan. Supernatan selanjutnya dilakukan uji kuantitatif bilangan asam menggunakan metode alkalimetri dan bilangan peroksida menggunakan metode iodometri.

\section{Pengumpulan Data Penelitian}

Data penelitian yang didapatkan dari pengukuran volume titrasi selanjutnya dihitung penetapan kadar bilangan asam dan peroksida sebagai berikut:

$$
\text { Bilangan Asam }\left(\mathrm{mg} \frac{\mathrm{KOH}}{\mathrm{g}}\right)=\frac{56,1 \times \mathrm{V} \times \mathrm{N}}{\mathrm{W}}
$$

$$
\begin{aligned}
\text { Keterangan: } & \mathrm{V}=\text { Volume titrasi }(\mathrm{mL}) \\
\mathrm{N} & =\text { Normalitas }(\mathrm{mol} \text { eq/L) } \\
\mathrm{W} & =\text { Massa Sample Minyak Jelantah }(\mathrm{mg})
\end{aligned}
$$


Bilangan Peroksida $\left(\right.$ mek $\left.\frac{\mathrm{O} 2}{\mathrm{Kg}}\right)=\frac{1000 \times \mathrm{N} \mathrm{x} \mathrm{A}}{\mathrm{W}}$

Keterangan: $\mathrm{N}=$ Normalitas (moleq/L)

$A=$ Volume larutan $\mathrm{Na}_{2} \mathrm{~S}_{2} \mathrm{O} 3$ yang digunakan pada peniteran sample minyak jelantah $(\mathrm{mL})$

$\mathrm{W}$ = Massa sample minyak jelantah (g)

(Fitriyana, 2015).

\section{Analisia Data Penelitian}

Data yang digunakan dalam penelitian ini didapatkan dari hasil pemeriksaaan bilangan asam dan bilangan peroksida pada minyak jelantah yang diberikan adsorben cangkang telur ayam pada temperatur tinggi dan rendah. Selanjutnya data tersebut dilakukan analisa data uji statistik univariat, kemudian dilanjutkan dengan uji statistik bivariat uji anova dengan tingkat kepercayaan $95 \%$.

\section{Ethical Clearance}

Penelitian ini telah melalui uji ethical clearance atas persetujuan komisi etik Poltekes Tanjungkarang. No. 145/EC/KEP-TJK/V/2018.

\section{HASIL}

Berdasarkan percobaan penambahan adsorben cangkang telur ayam pada minyak jelantah yang dilakukan pada temperatur tinggi $\left(180^{\circ} \mathrm{C}\right)$ dan temperatur ruang didapatkan hasil perbandingan penurunan kadar bilangan asam dan peroksida seperti terangkum dalam tabel 1 dan 2 sebagai berikut:

Tabel 1. Perbandingan Penurunan Bilangan Asam pada Pencampuran Adsorben Telur Ayam dengan Minyak Jelantah

\begin{tabular}{cccccc}
\hline \multirow{2}{*}{$\begin{array}{c}\text { Ulangan } \\
\text { Ke- }\end{array}$} & \multirow{2}{*}{$\begin{array}{c}\text { Kadar Bilangan Asam } \\
\text { Sebelum Intervensi }\end{array}$} & \multicolumn{4}{c}{ Hasil Penelitian Setelah Intervensi } \\
\cline { 3 - 5 } & 1,7 & T. Tinggi & Penurunan & T. Ruang & Penurunan \\
\hline 1 & 1,7 & 0,97 & 0,73 & 0,75 & 0,95 \\
2 & 1,7 & 1,01 & 0,69 & 0,73 & 0,97 \\
3 & 1,7 & 1,03 & 0,67 & 0,59 & 1,11 \\
4 & 1,7 & 0,99 & 0,71 & 0,63 & 1,07 \\
5 & & 1,12 & 0,58 & 0,61 & 1,09
\end{tabular}




\begin{tabular}{cccccc}
\hline \multirow{2}{*}{$\begin{array}{c}\text { Ulangan } \\
\text { Ke- }\end{array}$} & \multirow{2}{*}{$\begin{array}{c}\text { Kadar Bilangan Asam } \\
\text { Sebelum Intervensi }\end{array}$} & \multicolumn{3}{c}{ Hasil Penelitian Setelah Intervensi } \\
& & & & & \\
\cline { 1 - 1 } & & & & & \\
6 & 1,7 & 1,06 & 0,64 & 0,65 & 1,05 \\
7 & 1,7 & 1,02 & 0,68 & 0,72 & 0,98 \\
8 & 1,7 & 1,20 & 0,50 & 0,76 & 0,94 \\
9 & 1,7 & 1,12 & 0,58 & 0,72 & 0,98 \\
10 & 1,7 & 0,85 & 0,85 & 0,67 & 1,03 \\
11 & 1,7 & 1,17 & 0,53 & 0,63 & 1,07 \\
12 & 1,7 & 1,22 & 0,48 & 0,73 & 0,97 \\
13 & 1,7 & 1,01 & 0,69 & 0,72 & 0,98 \\
14 & 1,7 & 1,03 & 0,67 & 0,64 & 1,06 \\
15 & 1,7 & 0,97 & 0,73 & 0,61 & 1,09 \\
16 & 1,7 & 0,92 & 0,78 & 0,65 & 1,05 \\
\hline
\end{tabular}

Tabel 2. Perbandingan Penurunan Bilangan Peroksida pada Pencampuran Adsorben Telur Ayam dengan Minyak Jelantah.

\begin{tabular}{cccccc}
\hline \multirow{2}{*}{$\begin{array}{c}\text { Ulangan } \\
\text { Ke- }\end{array}$} & $\begin{array}{c}\text { Kadar Bilangan } \\
\text { Peroksida } \\
\text { Sebelum } \\
\text { Intervensi }\end{array}$ & \multicolumn{4}{c}{ Hasil Penelitian Setelah Intervensi } \\
\cline { 3 - 6 } & 31,6 & 18,56 & 13,04 & 8,23 & 23,37 \\
\hline 1 & 31,6 & 18,7 & 12,9 & 8,51 & 23,09 \\
2 & 31,6 & 19,7 & 11,9 & 7,98 & 23,62 \\
3 & 31,6 & 16,5 & 15,1 & 7,46 & 24,14 \\
4 & 31,6 & 20,8 & 10,8 & 7,23 & 24,37 \\
5 & 31,6 & 18,3 & 13,3 & 7,71 & 23,89 \\
6 & 31,6 & 19,2 & 12,4 & 8,45 & 23,15 \\
7 & 31,6 & 19,5 & 12,1 & 8,62 & 22,98 \\
8 & 31,6 & 19,1 & 12,5 & 8,35 & 23,25 \\
9 & 31,6 & 19,8 & 11,8 & 7,72 & 23,88 \\
10 & 31,6 & 19,1 & 12,5 & 7,53 & 24,07 \\
11 & 31,6 & 19,3 & 12,3 & 8,73 & 22,87 \\
12 & 31,6 & 20,3 & 11,3 & 8,61 & 22,99 \\
13 & 31,6 & 19,3 & 12,3 & 7,34 & 24,26 \\
14 & 31,6 & 18,4 & 13,2 & 7,38 & 24,22 \\
15 & 31,6 & 19,7 & 11,9 & 7,82 & 23,78 \\
16 & & & & & T. Tinggi \\
\hline
\end{tabular}

Selanjutnya untuk mengetahui perbedaan penurunan kadar bilangan asam dan peroksida dari penelitian ini, data tabel 1 dan 2 dianalisis bivariat uji 
independen T-tes dengan tingkat kepercayaan 95\% dengan hasil analisis seperti dituliskan padaTabel 3 dan 4 sebagai berikut:

Tabel 3. Distribusi Penurunan Nilai Bilangan Asam Pada Minyak Jelantah Menurut Perlakuan Temperatur Tinggi dan Temperatur Ruang

\begin{tabular}{cccccc}
\hline Perlakuan & Mean & SD & SE & P Value & N \\
\hline Temperatur Tinggi & 0,6487 & 0,09891 & 0,02554 & 0,000 & 16 \\
Temperatur Ruang & 100,227 & 0,05763 & 0,01488 & 0,000 & 16 \\
\hline
\end{tabular}

Rata-rata penurunan nilai bilangan asam pada perlakuan temperatur tinggi adalah 0,649 $\mathrm{mg} \mathrm{KOH} / \mathrm{g}$, dengan standar devisiasi 0,099. sedangkan rata-rata untuk penurunan nilai bilangan asam pada perlakuan temperatur rendah adalah 1,00227 mg KOH/g, dengan standar devisiasi 0,05763.

Hasil uji statistik didapatkan nilai $\mathrm{P}=0,000$, berarti pada a $5 \%$ terlihat ada perbedaan signifikan antara perlakuan temperatur tinggi dan temperatur rendah pada penurunan nilai bilangan asam.

Tabel 4. Distribusi Penurunan Nilai Bilangan Peroksida pada Minyak Jelantah Menuru Perlakuan Temperatur Tinggi dan Temperatur Ruang.

\begin{tabular}{cccccc}
\hline Perlakuan & Mean & SD & SE & P Value & N \\
\hline Temperatur Tinggi & 236,100 & 0,53547 & 0,13826 & 0,000 & 16 \\
Temperatur Rendah & 124,960 & 0,99180 & 0,25608 & 0,000 & 16 \\
\hline
\end{tabular}

Rata-rata penurunan nilai bilangan peroksida pada perlakuan temperatur tinggi adalah 23,6100 meq $\mathrm{O}_{2} / \mathrm{g}$, dengan standar devisiasi 0,53547 , sedangkan rata-rata untuk penurunan nilai bilangan peroksida pada perlakuan temperatur rendah adalah 12,4960 meq $\mathrm{O}_{2} / \mathrm{g}$, dengan standar devisiasi 0,25608.

Hasil uji statistik didapatkan nilai $\mathrm{P}=0,000$, berarti pada a $5 \%$ terlihat ada perbedaan signifikan antara perlakuan temperatur tinggi dan temperatur rendah pada penurunan nilai bilangan peroksida.

Selanjutnya untuk mengetahui temperatur efektif menurunkan bilangan asam dan peroksida pada minyak jelantah, dilakukan analisis univariat dengan 
hasil seperti Tabel 5 dan 6 sebagai berikut:

Tabel 5. Temperatur Efektif Saat Pencampuran Minyak Jelantah dengan Adsorban Cangkang Telur Ayam pada Penurunan Bilangan Asam.

\begin{tabular}{cccc}
\hline $\begin{array}{c}\text { Perlakuan Temperatur } \\
\text { Pada Bilangan Asam }\end{array}$ & Maximum & Minimum & Temperatur Efektif \\
\hline Tinggi & 0,85 & 0,48 & Temperatur ruang \\
Rendah & 1,11 & 0,94 & \\
\hline
\end{tabular}

Tabel 5 di atas dapat dilihat nilai maksimum penurunan nilai bilangan asam sebesar 1,11 pada perlakuan temperatur rendah, jadi temperatur yang efektif digunakan saat pencampuran minyak jelantah dengan adsorban cangkang telur ayam untuk menurunkan bilangan asam adalah temperatur ruang.

Tabel 6. Temperatur Efektif Saat Pencampuran Minyak Jelantah dengan Adsorban Cangkang Telur Ayam pada Penurunan Bilangan Peroksida.

\begin{tabular}{cccc}
\hline $\begin{array}{c}\text { Perlakuan } \\
\text { Temperatur Pada } \\
\text { Bilangan Peroksida }\end{array}$ & Maximum & Minimum & Temperatur Efektif \\
\hline Tinggi & 15,10 & 10,80 & Temperatur ruang \\
Rendah & 24,37 & 22,87 & \\
\hline
\end{tabular}

Pada Tabel 6 di atas dapat dilihat nilai maksimum penurunan nilai bilangan peroksida sebesar 24,370 pada perlakuan temperatur ruang, jadi temperatur yang efektif digunakan saat pencampuran minyak goreng jelantah dengan adsorban cangkang telur ayam untuk menurunkan bilangan peroksida adalah temperatur ruang.

\section{DISKUSI}

Menurut Fitriyana (2015), turunnya kadar asam lemak bebas dalam minyak jelantah disebabkan karena terserapnya senyawa asam lemak bebas pada sisi aktif dan luas permukaan yang terdapat pada adsorben cangkang telur ayam. Asam lemak bebas yang mempunyai ujung karboksil yang polar, sehingga bisa 
teradsorpsi oleh adsorben cangkang telur ayam yang sifatnya polar.

Berdasarkan hasil penelitian pada Tabel 1 penurunan maksimum kadar bilangan asam pada temperatur tinggi relatif lebih rendah terhadap perlakuan penambahan adsorben pada temperatur ruang, hal ini dikarenakan adsorben cangkang telur telah jenuh mengikat asam lemak, namun produk asam lemak terus terjadi karena pada temperatur tinggi senyawa minyak terus mengalami pemutusan ikatan membentuk asam lemak bebas (Mahfoudhi, 2020).

Menurut Dewi (2001), peroksida yang mengandung oksigen merupakan senyawa polar sehingga lebih mudah terikat pada adsorben yang bersifat polar. Adsorben cangkang telur memiliki komponen utama yaitu kalsium karbonat bersifat polar. Kekuatan interaksi adsorbat dan adsorben dipengaruhi oleh sifat dari adsorbat maupun adsorbennya, seperti kepolaran adsorben dan adsorbat. Apabila adsorbennya bersifat polar maka komponen yang bersifat polar akan terikat lebih kuat dibandingkan dengan komponen yang kurang polar. Daya adsorpsi melibatkan gaya van der walls dimana terjadi tarik menarik antar molekul.

Berdasarkan Tabel 2 nilai penurunan maksimum kadar bilangan peroksida pada temperatur tinggi relatif lebih rendah terhadap perlakuan penambahan adsorben pada temperatur ruang, hal ini dikarenakan adsorben cangkang telur telah jenuh mengikat senyawa peroksida, namun reaksi pembentukan senyawa peroksida yang berasal dari asam lemak bebas bereaksi dengan okisgen di udara membentuk senyawa peroksida terus berlangsung hingga pada kurun waktu tertentu asam lemak bebas habis bereaksi seluruhnya (Zhang, 2019).

\section{KESIMPULAN}

1. Berdasarkan hasil analisis bivariat uji Independen T-test dengan tingkat kepercayaan 95\%, terdapat perbedaan signifikan penurunan nilai bilangan asam pada perlakuan temperatur tinggi dan ruang $(P$ value $=0.000)$, demikian juga terdapat perbedaan signifikan penurunan nilai bilangan peroksida pada perlakuan temperatur tinggi dan ruang $(P$ value $=0.000)$. 
2. Temperatur efektif digunakan saat pencampuran minyak jelantah dengan adsorben cangkang telur ayam untuk menurunkan bilangan asam dan peroksida adalah temperatur ruang.

\section{UCAPAN TERIMAKASIH}

Penulis sangat berterimakasih atas kesempatan yang diberikan oleh Poltekkes Tanjungkarang untuk melaksanakan penelitian skema peneliti pemula sesuai SK Direktur No HK.02.03/1.2/2712/2018, semoga penelitian ini dapat bermanfaat bagi pengembangan pemanfaatan minyak jelantah menjadi produk yang lebih berguna.

\section{KONFLIK KEPENTINGAN}

Tidak ada konflik kepentingan dalam penelitian ini.

\section{REFRENSI}

Dewi, S. (2011). Pemanfaatan Piropilit Sebelum dan Sesudah Aktivasi Sebagai Adsorben pada Proses Penurunan Bilangan Peroksida dan Kadar Asam Lemak Bebas Minyak Jelantah. Jurnal Manusia dan Lingkungan, 18(2), 184-190.

Fitriyana. (2015). Pemanfaatan Cangkang Telur Ayam Sebagai Adsorben Untuk Meningkatkan Kualitas Minyak Jelantah. Pemanfaatan Cangkang Telur Ayam Sebagai Adsorben Untuk Meningkatkan Kualitas Minyak Jelantah, 4(1), 12-16.

Hartono, R. (2020). Pemurnian Minyak Jelantah Dengan Menggunakan Steam Pada Kolom Vigrek Dan Katalis Zeolit Alam Bayah. Jurnal Integrasi Proses, 9(1), 20-24.

Mahfoudhi, N. (2020). Porous material from cellulose nanfibrils coated with aluminum hydrxyde as in effetive for fluoride. Journal of Environmental Chemical Engineering, 8(3), 103779.

Parvin, S. (2019). Study on adsorption of Congo red onto chemically modified egg shell membrane. Chemosphere, 236, 124326.

Schneider, L. T. (2019). Use of rice husk in waste cooking oil pretreatment. Environmental Technology (United Kingdom), 40(5), 594-604.

Yulianti, E. (2018). Pemanfaatan Biosorben Batang Jagung Teraktivasi Asam Nitrat dan Asam Sulfat untuk Penurunan Angka Peroksida - Asam Lemak 
Bebas Minyak Goreng Bekas. Alchemy, 5(1), 9.

Zhang, Z. (2019). A novel adsorbent of core-shell construction of chitosancellulose magnetic carbon foam: Synthesis, characterization and application to remove copper in wastewater. Chemical Physics Letters, 731(June), 136573. 